\title{
Red Sea Islands
}

\author{
By ALBReCht HofHeINZ
}

"We're back to the Square" (Răği ìn il-Mìdān), activists proclaim when the news breaks in April that Egypt is ceding sovereignty over two strategically important islands in the Red Sea to Saudi Arabia. Back to the iconic Tahrir Square, back to the days of glory when the people stood up to a despotic ruler: to take back our dignity, that is the wish, the hope that many would like to rekindle when they call for demonstrations on the "Friday of Dignity" (Ğum'at al-Karāma) under the slogan "Our Land is Our Honour" (al-Arḍ hiya 'l-'irḍ).

Let today be a new beginning [...] Those going out to demonstrate today are asserting 'I'm here! I'm still here, and I have an opinion, a voice, a value. Together we are stronger. There are many who still hold on to the embers of our dream, our hope. The January Revolution is still alive; it has left its mark in us despite everything that has happened. The blood of thousands of martyrs, the tribulations of thousands of detainees have not been in vain and will not be in vain. Today we can build the first brick in the wall of hope, and tear down the wall of fear.

Such sentiments are shared not only by those who sympathize with the outlawed 6 April Movement but also by the Islamically-oriented political opposition [ $\nearrow$ Hope vs. Hell]. "This is a golden opportunity to transcend the Army/Brotherhood dichotomy sown by the counterrevolution," tweets Țāriq al-Zumar, exiled head of the Building and Development Party, the political arm of the formerly jihadist group al-Ğamā a al-Islämiyya. Somewhat cautiously given the power structures in place he asks, "Will we succeed?" The Twitter hashtag \#Ğum'at al-Ard (\#Land_Friday) is used over 100,000 times, but street demonstrations on 15 and again on 25 April (Sinai Liberation Day) meet with limited response in view of heavy state security presence at public rallying points. Even so, protest marches take place throughout the country, and several thousand demonstrators turn out at the Press Syndicate, making this the largest such rally since the introduction of the protest law made any demonstration consisting of more than ten people subject to prior police approval. The police act with relative restraint; no-one is killed, and 'only' hundreds, not thousands of people are arrested. Clearly, the authorities sense the depth of public fury over what many regard as a "sell-out of Egyptian land". The deal with Saudi Arabia is part of a package of 14 protocols that include a 16 billion dollar investment package, soft loans, and a bridge to facilitate trade between the two countries. Egypt is to receive 2 billion USD yearly, plus a $25 \%$ share in the proceeds from oil and gas extracted from the area. The financial benefits are conditional on Egypt signing the maritime border agreement that settles the century-old uncertainty regarding sovereignty over the islands Tīrān and Șanāfīr in Saudi Arabia's favor. This linkage is not lost on critical observers. 'Here is the army that is supposed to defend our country's territorial integrityand what do they do? They sell it piecemeal to the rich (and unbeloved) neighbor, for a few breadcrumbs in the hope of prolonging their rule.' Mașr mish lil-bï ("Egypt is not for sale") is one of the earliest slogans demonstrators hold up on the street, and it quickly spreads to social media. The rallying cry strikes a chord among wide sections of the public, and criticism

Journal of Arabic and Islamic Studies • 21 (2021) - Themed Section In2016: *233-*240 (C) Alrecht Hofheinz, Dept. of Culture Studies and Oriental Languages (IKOS), Univ. of Oslo, NO 
is voiced even on pro-government media such as ON TV, Dream, CBC, and al-'Āṣima. Feeling the fire, President Sisi is quick to explain that he is "not squandering a grain of sand" of Egyptian soil. The semi-official al-Ahrām runs an editorial affirming that "Egypt has not surrendered a single square inch of its territory under any condition. But it will be unreasonable to deny our brothers their right to hold on to their own territory when all documents prove their ownership." Both the government and the opposition proceed to publish maps and refer to select events and agreements in the past to support their position, but a dispassionate discussion of the mutual claims in the light of a balanced account of historical and geographical facts is not on the agenda. Rather, declarations of confidence in the President and the Army meet an outraged feeling of having been duped. Under the hashtag \#kullinā_ìd_wāhda_macal-Sĭsī ("We're all one hand with Sisi"), people affirm their trust in the President "who has done more for our country than what has been achieved in previous decades," and they explain the wisdom behind his decision:

There's no selling of any island! The ball is now in the Saudi camp [...] Egypt is now freeing itself from Camp David [...] When the bridge is built, Egypt will have military bases on the two islands [...] meaning a blockade of the Zionists. But don't waste your time trying to explain; people won't listen except to what they want to hear.

The other side is equally passionate. 'We have defended these islands with our blood; we shall not abandon them!' goes the narrative, for example on Facebook where people mobilize for demonstrations under the heading "Over our dead bodies". Reference is to the role the islands played in the 1956 and 1967 wars with Israel. "When the two islands needed to be defended and blood had to be shed in the struggle with the Zionist entity that was founded through rape and survives through aggression, it was only Egypt and its soldiers who paid with their lives in defence of these islands, confirming with their blood that they belong to Egypt" writes Aḥmad al-Nağğăr, Chairman of the Board of Directors of al-Ahrām in an article that he puts out on Facebook after having been prevented from publishing it in his own paper. Have not generations of Egyptian schoolchildren learned that these islands are part of the land of Egypt, and sung patriotic songs glorifying the army's defence of them? Stunned, they now discover that they have been quietly removed from the new school atlas. Why this sudden change? Part of the public reaction is anger about not having been informed, about the consultative and legislative bodies not having been consulted, about not having been given a voice in deciding the fate of the country [ $\nearrow$ Voice $v$ s. Silence]. "I am an Egyptian citizen, and I did not grant Sisi and his regime any mandate to sell or give up any piece of Egyptian land", tweets prominent human rights lawyer Ğamāl 'Īd, in line with countless similar statements on social media. The revelation that Israel—still the arch-enemy for the great majority of Egyptians - has been consulted, but not the Egyptian parliament, does not help calm the waters. Government officials and the President himself find it necessary to address this feeling of having been presented, all of a sudden, with a fait accompli. "The maritime border agreement", they explain "was not a sudden decision taken during the visit of King Salmān to Egypt. It is the result of six years of studies" by a dedicated committee. "Had I announced this eight months ago, we would have had the same controversy, and it would have weakened our negotiating position", Sisi lectures the nation. None of these explanations, however, help to defuse the resentment among those who are not convinced to 
begin with that whatever Sisi does is good for the country ("because I love him and have to stand by his side just as he stood with us against the people of evil"). Even police officers have qualms; the news that 150 of them are publicly calling for mass protest demonstrations is eagerly shared on social media, as is the dissenting voice of a former army officer. The thousands who do turn out on 15 April, defying the protest law, braving tear gas and the danger of being arrested, are trying to revive the spirit of 2011, and eventually, the old slogans "Leave!" and "The people want the fall of the regime" are being heard again. To the other side, this merely proves that

the enemy and consorts are playing their last card. For them, this is not really about Tīrān and Șanāfir. This is about destroying the state once again. It's the same scenario. The slogan 'Down with military rule' and 'the fall of the regime' - whom do they really serve??????? May God protect Egypt and its people and its army from every evil!

In fact, public outcry over the islands serves to vent anger over broader issues. "It's not just about the islands," explains Khālid Dāwūd, spokesman for a coalition of social-liberal parties. "It's about the overall performance of President Sisi, the way he treats us, the unilateral decisions, the arrests of young men and women." Ten days after the initial demonstrations, Sinai Liberation Day (25 April) provides a fitting occasion for new protest calls. The turnout is more limited, however, given that the security forces warn that they "will not again permit any illegal demonstrations" since these "aim at destroying the country," and set up "fixed and movable checkpoints" they themselves refer to as "ambush" [ $\nearrow$ Kamīn]. At the official celebration, Sisi leans on nationalist geographer Ğamāl Hamdān to conjure up the image of Sinai as "Egypt's holiest of holies" and reassures his audience that "the Egyptian armed forces, which are of the people and for the people, and all the Egyptian national institutions are aware of and appreciate the importance of preserving the national soil, and they have not and will not squander one grain of sand belonging to the land of Egypt". He calls on all Egyptians to "stand as one block" to defend these institutions against the "forces of evil" since "their survival is essential for the survival of the Egyptian State [...] We will not allow anyone to meddle with Egypt's security, stability and institutions." Hundreds of demonstrators who defy the official narrative that the two islands have merely been under Egyptian trusteeship are arrested and join the crowd of previous protesters facing trial for sedition. An editorial in the daily al-Yawm al-Sābic uses what it calls "unimpassioned analysis" to explain the reasons behind this clampdown: "We are good and you are evil"this is the message of the hard-working, simple and honest citizens to the "self-appointed elite who set themselves up as exclusive spokespersons for the people" while "calling for chaos and destruction". On the one hand, thus, "we see the salt of the earth, the simple and poor Egyptians, rising early in the morning to celebrate the liberation of Sinai $[\ldots]$ confirming that they are the real shields protecting the security and safety of this nation". On the other, we find

conspirators and traitors, secretly launching plans to throw Egypt in the mire of chaos, using all the tools of mischief and depravity, trying to obtain huge sums of money in exchange for their treason, in the form of funds from abroad, and traveling to the world 
centre of treason, the United States of America, and Britain, to stay there and get scholarships.

These "mercenary activists" attempt

to launch a new episode in the series of plots aimed at bringing down Egypt through calls for demonstrations demanding to overthrow the army and the police and to topple the current regime, in full coordination with the Terrorist Brotherhood, repeating the vile and despicable scenario of handing over the country to the Brotherhood, nay to ISIS, choosing national holidays cherished by every honourable patriot, as if to take revenge on Egypt for the benefit of its enemies: Israel, Qatar, Turkey and the United States of America.

“Good Lord!” exclaims eminent journalist Ibrāhīm 'T̄sā. "Those who stand up for the integrity of Egyptian territory are accused of being traitors, foreign agents, and conspirators! This is mind-boggling!" He is not the only one stupefied over this inversion of meaning: that the surrender of territory is dressed as "an act of patriotism that the masses have to celebrate," while any "refusal to dance along to this tune" is denounced as treason. Such an abuse of patriotic feelings to prop up a "militaristic regime" will lead to a "breakdown of the notion of patriotism," warns a human rights blogger.

People are being blackmailed emotionally through the phrase 'Long live Egypt' that is supposed to express love for one's country. Its automatic, hollow repetition strips it of all value and meaning, and it becomes a dictatorial slogan just like 'Heil Hitler', a slogan that everyone mindlessly has to repeat, or else they get to be traitors.

Others, however, criticize the prevailing public focus on land, honour and nation, trying to draw attention to more "real" concerns. "I believe the primary motto used by protesters on April 25, 'Land is Honour,' is isolated from the reality on the ground, to say the least," writes human rights activist Muḥammad $\mathrm{Na}^{\mathrm{C}} \mathrm{i} m$ :

The essence of any real democratic movement in Egypt must be based on a call for freedom, not a dispute over land, especially uninhabited islands like Tiran and Sanafir $[\ldots]$ The real land is the streets where we have become afraid to walk, the football fields that we are denied entry into, the land illegally acquired and divided up among the bureaucratic elite to accumulate ever more real estate [...] The land, in short, is not the dust and the mud that we stand on, but the suffering we face in our daily lives.

While the significance and meaning of the "land" question continues to be debated on the streets and in the media, left-wing former presidential candidate Khālid 'Alī takes the matter to court on the grounds that the constitution forbids the sale of Egyptian soil. It turns out that the judiciary is as divided on the issue as the rest of the country. After two months of deliberations, a lower administrative court declares the transfer illegal, a decision that is overturned on appeal another three months later, only to be reinstated again by yet another administrative injunction, whereupon the matter is referred to the Supreme Administrative Court [ $\lambda$ Court Trials]. Every time, supporters of the respective ruling erupt in small manifestations of public jubilation, but larger street demonstrations return to what they have been: a thing of the past. Only social media flare up again, reviving the hashtag \#Tiriñn_wi-

jais • 21 (2021) - Themed Section In2016: *233-*240 
Șanâfir_Mașriyya ("Tīrān and Șanāî̀r are Egyptian") when, at the end of the year, the government decides not to wait for the outcome of the judicial process and starts preparing the transfer of the two islands to Egypt's big brotherly neighbor.

\section{Related Entries}

ARRAYS - Court Trials Kamīn

CODES - Hope vs. Hell $\downarrow$ Voice $v s$. Silence

CODES ColLAPSED - Present $=$ Past $($ Stuck $)$

\section{References}

'ABD AL-GHANī, Sūzān. "Wathā’iq ğadīda: 22 kharīta min muqtanayāt Ğāmi'at Stānfōrd tuthbit milkiyyat Miṣr li-'Tīrān wa-Ṣanāfïr." Al-Bidāya, April 14, 2016, <http://albedaiah.com/news/2016/ 04/14/111075>.

'ABD AL-RĀZIQ, Mușțafà, and Thābit 'ABD AL-GHAFFĀR. "Masīrat al-Misāḥa tattaǧih li-muhīṭ Maḥaț̣at al-Buhūth ba'da iṭlāq al-shurța qanābil al-ghāz." Dōt Maṣr, April 25, 2016, <http://www.

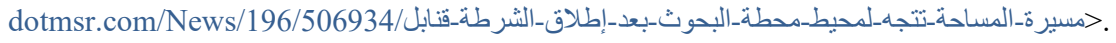

ABŪ 'L-MAKĀRIM, Ḥusām, and Shaymā’ Hillmī. "Ğisr Sulaymān... Sharayān ḥayāt ğadīda li-Miṣr wa-



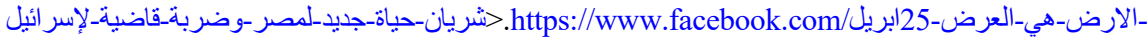

'ĀDIL, Ḥāzim. "Nanshur haythiyyāt ḥukm al-Qaḍā’ al-Idārī bi-buṭlān ittifāqiyyat tarsīm al-ḥudūd mac al-Sa'ūdiyya." Al-Yawm al-Sābic, June 21, 2016, <https://www.youm7.com/story/2016/6/21/- نتش

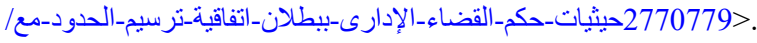

[al-Ahrām =] N. N. "Ta’ğîl ța’n 'Tīrān wa-Șanāfïr' ilā 3 yūliyū bi-sabab 'radd al-maḥkama."” Al-Ahrām, June 27, 2016, <https://www.evernote.com/1/AmRghotTi_NCrpq1sFx4BBB-unOBOKFTgDc>.

[Ahram Canada =] N. N. "Mișr tatanāzal 'an ğazīratay Tirān wa-Șanāfïr lil-Sa'ūdiyya muqābil 2 milyār dōlār sanawīyan wa-25\% min al-ghāz wa'l-bitrūl." Ahram Canada, April 8, 2016, <http:// www.ahram-canada.com/100676/>.

ALI, Khaled. "Facebook Post," June 15, 2016, <https://www.facebook.com/khaled.ali.72/posts/ $859664817512211>$.

Amw770. “Twitter Post @amw770.”Twitter, April 17, 2016, <https://twitter.com/amw770/status/ $721776048279535620>$.

'ĀZIR, Sharīf. “An inhiyār mafhūm al-wațaniyya,” April 26, 2016, <https://is.gd/1 eyYtX>.

BINS'AYYID, 'Imād. "Haaretz: Miṣr a'lamat Isrā̄̄l musbaqan bi-anna-hā sa-tatanāzal 'an al-jazīratayn


السعودية-جزر -تير ان-صنافير -اتفاق_معبر -قو ات_دولية_سيناء-سلام.

[CNN Arabic =] N. N. “Ğum`at "al-Arḍ hiya 'l-'irḍ"... tawāğud amnī mukaththaf bi-mayādīn ra’̄̄siyya [...]." CNN Arabic, April 15, 2016, <https://arabic.cnn.com/middleeast/2016/04/15/egyptdemonstration-friday-islands>.

DABASH, Hamdī. ““Amn al-Ǧīza': Ta 'īmāt bi'l-qabḍ 'alà 'l-mutaz̄āhirīn [...].” Al-Mașrī al-Yawm, April 24, 2016, <https://www.almasryalyoum.com/news/details/935682>.

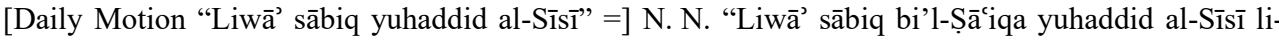
bay'ihī ğuzur Tīrān wa-Ṣanāfïr." Daily Motion, n.d. [2016], <https://www.dailymotion.com/ video/x45hxzy>.

[Facebook "al-Arḍ hiya 'l-irḍ" =] N. N. "al-Arḍ hiya 'l-irḍ 25 Abrîl." Facebook Group, n.d., <https://www.facebook.com/1566180717008446-84-الارض-هي-العرض-25|بريل'، "Facebook Post."

jais • 21 (2021) - Themed Section In2016: *233-*240 
6th of April Movement, April 15, 2016, > https://www.facebook.com/shabab6april/posts/-l

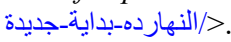

[Facebook "Mașr mish lil-bî̄" =] Facebook Page, n.d. [2016], <https://www.facebook.com/ Egyptisnotforsale/>.

FAHIM, Kareem. "Egyptians Denounce President Sisi in Biggest Rally in 2 Years." New York Times, April 15, 2016, <https://www.nytimes.com/2016/04/16/world/middleeast/cairo-protesters-denounceegyptian-president-sisi.html>.

[\#Ğum'at al-Arḍ =] “Ǧum'at al-Arḍ.” Twitter Hashtag, 1 January - 31 December 2016, <https://twitter. com/search?1=\&q=\%2320\% جمعة_الارضsince\%3A2016-01-01\%20until\%3A2016-12-31\&src=typd>.

al-ḤANAFī, Hiba. "Ghaḍab ba'da muwāfaqat al-ḥukūma 'alà 'Tīrān wa-Șanāfìr." Al-Maṣrī al-Yawm, December 30, 2016, <https://www.almasryalyoum.com/news/details/1064937>.


April 13, 2016, <https://www.almasryalyoum.com/news/details/928512>.

[Harakat Shabāb $6 \mathrm{Ibrīl}=$ ] N. N. Facebook post, posted on April 15, 2016, < Harakat Shabāb 6 Ibrīl $>$.

al-HAwĀRĪ, Dandrāwī. "Al-Busațā̄ li-"Ṣabāḥ̄ wa-Abū al-Futūḥ wa'l-Barādicī": naḥnu al-khayr waantum al-sharr." Yawm Al-Sābic, April 26, 2016, <https://www.youm7.com/story/2016/4/



[al-Hurriyya lil-ğad'ān =] N. N. "Facebook Post.” al-Hurriyya lil-ğad'ān, April 28, 2016, <https:// www.facebook.com/A17oriallgd3an/posts/848751205236740>.

'ĪD, Ğamāl. “Twitter Status @gamaleid.” December 29, 2016, <https://twitter.com/gamaleid/status/ 814502085895094273>.

[\#Kullinā ìd wāḥda mac al-Sīsì =] "Kullinā īd wāḥda ma c al-Sīsī." Twitter Hashtag. 1 January - 31

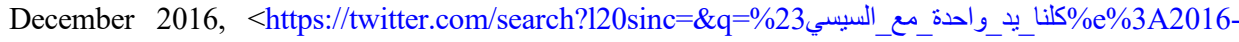
01-01\%20until\%3A2016-12-31\&src=typd $>$.

[Mada Masr (a) =] N. N. "Police Arrest Dozens in Late Night Raids across the Country." Mada Masr, April 22, 2016, <https://madamasr.com/en/2016/04/22/news/u/police-arrest-dozens-in-late-nightraids-across-the-country-2/>.

[Mada Masr (b) =] N. N. "Update: More Members of Online Satirical Troupe Arrested." Mada Masr, May 9, 2016, <https://madamasr.com/en/2016/05/09/news/culture/update-more-members-ofonline-satirical-troupe-arrested/>.

[IDSC =] N. N. "Ǧazīratay Tīrān wa-Șanāfîr tābi ān li-l-Milkiyya al-`Arabiyya al-Sacuudiyya.” Markaz alMa'lümāt wa-Da'm Ittikhādh al-Qarār, Mağlis al-Wuzarā’ al-Mișrī, April 12, 2016, <https://web. archive.org/web/20160418122133/http:/www.idsc.gov.eg/IDSC/News/View.aspx?ID=4269>.

MARwA. “Twitter Post @MarwaOkasha,”April 15, 2016,<https://twitter.com/MarwaOkasha/status/ 720872135279779840>.


Online, April 11, 2016, <http://alamatonline.com/archives/39658>.

MiRa Mohamed. “Twitter Post @Mira_MOha,”April 15, 2016, <https://twitter.com/Mira_MOha/ status/720968468959465473>.

Монав. “Twitter Post @mohabart,” April 12, 2016, <https://twitter.com/mohabart/status/ 719999407295492096>.

Mony Gamal. “Twitter Post @Monygam26611642.” Twitter, April 14, 2016, <https://twitter.com/ monygam26611642/status/720850205256515584>.

[Al-Mūğaz=] N. N. "Lil-tārīkh wa-qabla tabdīl al-mawāqif: mā qālahū 'l-i'lāmiyyūn 'an qaḍiyyat Tīrān wa-Șanāfīr.” al-Mūğaz, April 13, 2016, <https://web.archive.org/web/*/http://almogaz. com/news/politics/2016/apr/13/2235597>.

jaig • 21 (2021) - Themed Section In2016: *233-*240 
[Muhammad AL-'Umda =] al-'Umda, Muhammad. "Twitter Post @mohamedelomda77.” Twitter, April 14, 2016, <https://twitter.com/mohamedelomda77/status/720797318841286656>.

MuḤYĪ, Mușțafà. "Bi'l-ṣuwar... Wathā’iq ğadīda tuthbit miṣriyyat Tīrān wa-Șanāfìr." Mada Masr,

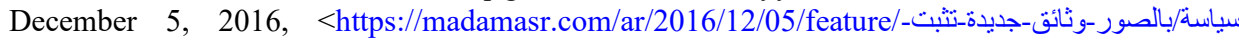

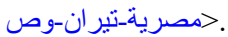

[Nabḍ Al-Hurriyya =] N. N. "150 ḍābiṭ miṣrī yưlinū rafụahum bay al-Sīsī lil-ğuzur." Nabḍ alHurriyya, April 17, 2016, <https://web.archive.org/web/20160419200723/http:/nabdalhoria.com/ archives/14486>.

NĀBULIYŪN, Muḥammad. “al-Qaḍāà al-idārī yulzim al-ra'̄̄s wa'l-ḥukūma bi-tanfīdh ḥukm miṣriyyat "Tīrān wa-Șanāfîr." Al-Shurūq, November 8, 2016, <http://www.shorouknews.com/news/view. aspx?cdate=08112016\&id=b0ec7be4-6f51-46ef-b70d-83acdbd87216>.

al-NAĞĞĀR, Aḥmad. “Tīrān wa-Ṣanāfìr wa-qawā'id ta’sīs al-awțān wa'l-duwal.” Facebook Post, April 17, 2016, <https://www.facebook.com/permalink.php?story_fbid=10154196545389884\&id=611234883>.

NAEEM, Mohamed. "April 25: A crack in the wall of fear?" Mada Masr, April 28, 2016, <https:// madamasr.com/en/2016/04/28/opinion/u/april-25-a-crack-in-the-wall-of-fear/>, orig. Arabic: Muḥammad NA ĪM, "Marḥalat shaqq al-ğidār: as'ila hawla 'l-'awda lil-shāri'," Mada Masr, April 26,

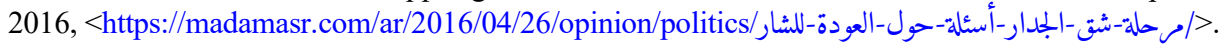

["Over our dead bodies" =] N. N. “Alà ğuththatnā." Facebook Event, Created by Harakat Shabāb 6 Ibrīl, April 15, 2016, <https://www.facebook.com/events/1586440928333688/>.

al-QARANSHĀWĪ, Shaymā’. 'Khālid 'Alī: 'al-Ta'līm' hadhafat ğuz' 'mișriyyat Tīrān wa-Șanāfîr' min kitāb ğughrāfiyā." al-Mașrī al-Yawm, November 7, 2016, <https://www.almasryalyoum.com/ news/details/1036581>.


September 26, 2016, <https://www.raialyoum.com/?p=529705>.

RAvid, Barak, Jack Khoury, Gili CoHEN, and The Associated Press. "Egypt Informed Israel in Advance of Plan to Hand Over Red Sea Islands to Saudis." Haaretz, April 11, 2016, <https://www. haaretz.com/middle-east-news/egypt-informed-israel-in-advance-of-handover-of-red-sea-islandsto-saudis-1.5429897>.

SAMīKA, Muḥsin. "Kalimat al-Sīsī fì dhikrà taḥrīr Sīnā̄." Al-Mașrī al-Yawm, April 24, 2016, <https:// www.almasryalyoum.com/news/details/935678>.

[Tahrīr =] N. N. "Ghadan... Masīrāt Ğum'at 'al-Arḍ hiya 'l-'irḍ' li-raf̣̣ al-tanāzul 'an 'Tirān wa-



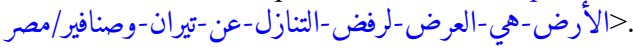

al-TALĀWĪ, Aḥmad. "Tarsīm al-ḥudūd al-mișriyya - al-Sa ūdiyya: qaḍāyā wa-ishkāliyyāt." Al-Machad al-

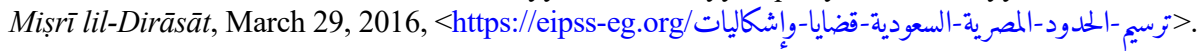

The Traveller. “Twitter Post @Nassefovic,” April 15, 2016, <https://twitter.com/Nassefovic/ status/720982874351104000>.

[\#Tīrān_wi-Șanāfîr_Mașriyya =] "Tīrān_wi-Șanāfīr_Mașriyya.” Twitter Hashtag, 1 January - 31

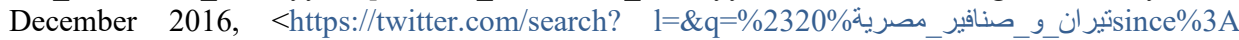
2016-01-01\%20unti1\%3A2016-12-31\&src=typd>.

WALSH, Declan. "Lawyer's Arrest in Egypt Signals Determination to Quell Criticism." The New York Times, May 6, 2016, <https://www.nytimes.com/2016/05/07/world/middleeast/egypt-malek-adlyabdel-fattah-el-sisi.html>.

[YT "Hāydī Fārūq" =] N. N. Hāyd̄̄ Fārūq ğazīratay [sic] Tīrān wa-Șanāfìr mișriyyatān ON Sabāh. YouTube video, uploaded May 12, 2016, <https://youtu.be/mz26NmcChd8>.

jais • 21 (2021) - Themed Section In2016: *233-*240 
ZALṬA, Shādī 'Abd Allāh. "Lam wa-lan nufriṭ ḥabbat turāb min arḍ Miṣr.” Al-Ahrām, n.d [2016], $<$ http://www.ahram.org.eg/NewsQ/503955.aspx>.

al-ZumAR, Țarīq. “Twitter Post @drtarekelzomor,” April 14, 2016, <https://twitter.com/ drtarekelzomor/status/720857515710218240>.

4 albrecht.hofheinz@ikos.uio.no 